\title{
UPPER PLEISTOCENE GULO GULO (LINNÉ, 1758) REMAINS FROM THE SRBSKO CHLUM-KOMIN HYENA DEN CAVE IN THE BOHEMIAN KARST, CZECH REPUBLIC, WITH COMPARISONS TO CONTEMPORARY WOLVERINES
}

\author{
Cajus G. Diedrich ${ }^{1}$ and Jeffrey P. Copeland²
}

\begin{abstract}
Wolverine bone material is described from the famous Upper Pleistocene cave Srbsko Chlum-Komin in the Bohemian Karst, Czech Republic, along with an overview of recently known Czech sites. The Gulo gulo Linné material was found in one of the largest Ice Age spotted-hyena dens in Europe. As a result of non-systematic excavations, the taphonomy is partly unclear. Lower-jaw remains indicate a minimum of three wolverines. Two of the mandibles are cracked, which is most likely the result of carnivore scavenging. The absence of juvenile G. gulo suggests possible importation of the wolverines by hyenas Crocuta crocuta spelaea Goldfuss.
\end{abstract}

\section{INTRODUCTION}

The vertical caves of the Chlum quarry near Srbsko in Central Bohemia, Czech Republic (Fig. 1) provide sediments and bone rich caves ranging from Middle to Upper Pleistocene (Diedrich and Žák, 2006). The most important Upper Pleistocene site in the Bohemian Karst, and arguably in Europe, is the vertical cave Srbsko ChlumKomin (Fig. 1). During the Upper Pleistocene, the Ice Age spotted hyena Crocuta crocuta spelaea (Goldfuss, 1823) is believed to have imported large quantities of prey remains into the Komin Cave, including complete carcasses. This site provides the largest deposit of hyena-den bone material in Europe. A general overview of the fauna was given by Diedrich and Žák, (2006).

\section{Geological and Taphonomical Setting}

The Chlum-Komin Cave was originally discovered and poorly excavated between 1958 and 1972, primarily by a local speleoclub, and unfortunately, without documentation. Mammal deposition was first thought to be of trapped animals, animals that dropped into the cave, or bones that washed in (Beneš, 1970). Diedrich and Žák (2006) concluded that a clan of the Late Pleistocene spotted hyena $C$. crocuta spelaea used this cave over generations as their den, as evidenced by the abundant presence of hyena bones or partial skeletons, their coprolite material, and chewed and cracked prey bones. The Komin Cave is more or less sloping and in some parts vertical; the entrance was destroyed by the quarry activities. The Komin is connected to a larger, horizontal cave system. Diedrich and Žák (2006) argued that this chimney did not function as a trap and was clearly accessible to hyenas. The Komin contained 3,569 macromammal bones, most notably 350 remains of hyena bones constituting five partial hyena skeletons, including three juveniles, one adult male, and one adult female. Evidence of crushed hyena long bones indicate hyena cub raising and cannibalism as well (Diedrich and Žák, 2006). Prey remains consisted of Przewalski horse (Equus ferus przewalskii, including one embryo skeleton), (Diedrich and Zák, 2006), woolly rhinoceros (Coelodonta antiquitatis), steppe bison (Bison priscus), reindeer (Rangifer tarandus), chamoix (Rupricapra rupricapra), ibex (Capra ibex), wolf (Canis lupus), and the herein detailed wolverine material (Gulo gulo) (Fig. 2). Finally, the presence of a two- to three-year-old lioness (Panthera leo spelaea) with a skull injury, as well as a lion cub about one year of age (Diedrich, 2009a), may indicate either antagonistic conflicts between hyenas and lions in the cave itself or the importation of these individuals as hyena prey.

Chewing and cracking of bones by hyenas is particularly evident on specimens of woolly rhinoceros and steppe bison, as is evidence of hyena cannibalism ( Diedrich and Žák, 2006; Diedrich, 2007). This site was also believed to have been used by common foxes (Vulpes vulpes). Tens of thousands of micromammal bones have been identified from fox scat and snowy owl (Nyctea scandiaca) pellets in the Komin Cave.

\section{Systematic Palaeontology}

Sixteen wolverine bones collected from this cave are housed at the National Museum Prague and Museum of the Bohemian Karst Beroun.

\section{Family Mustelidae Swainson, 1835}

Genus Gulo Pallas, 1780

Gulo gulo (Linné, 1758)

Four mandibles of at least three individual adult-tosenile wolverines are represented (Figs. 3, 4.1-4.4). Two of

\footnotetext{
${ }^{1}$ Cajus G. Diedrich, PaleoLogic, Nansenstr. 8, D-33790 Halle/Westphalia, Germany; cdiedri@gmx.net

${ }^{2}$ Jeffrey P. Copeland, USDA Forest Service, Rocky Mountain Research Station, 800 E. Beckwith, Missoula, Montana 59801, USA; jpcopeland@fs.fed.us
} 


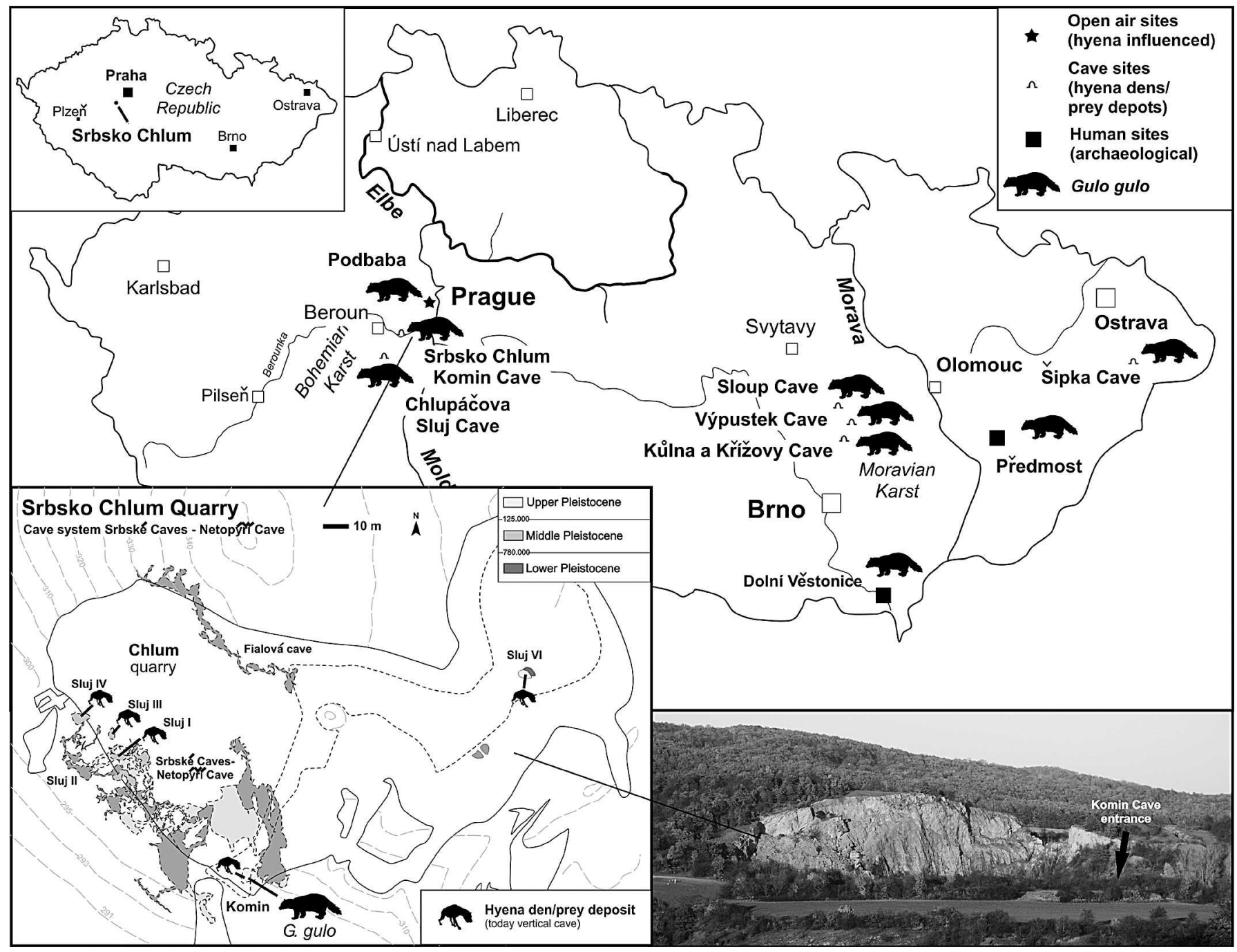

Figure 1. Positions of wolverine G. gulo (Linné, 1758) sites in Czech Republic focusing on the Bohemian Karst and adjacent areas around Prague, Czech Republic. Srbsko quarry caves have provided thousands of bones from the Middle to Upper Pleistocene.

them are nearly complete, lacking only incisor teeth. The other two (Figs. 4.3 and 4.4) were cracked by carnivores, with the ramus missing. One mandible is from an adult animal (Fig. 4.2), two are from old-age adult wolverines (Figs. 4.1 and 4.3), and the fourth represents an older individual, as evidenced by severely worn teeth (Fig. 4.4). A single canine tooth without half of the used cusp (Fig. 4.5) is, again, from an older animal. Additionally, two incisor teeth (not figured, Table 1) are from adult-tosenile animals.

The postcranial material is from adult-to-senile individuals and consists of a right complete radius (Fig. 4.6) and a right complete ulna (Fig. 4.7). Two metacarpi, one recently damaged (Fig. 4.12) and one complete left Mc IV (Fig. 4.13), are from the manus skeleton. The hind limb bones include a distally incomplete left femur (Fig. 4.8) that was damaged during the excavations. Also the right and left tibia bones (Figs. 4.9 and 4.10) are similar in length $(14.6 \mathrm{~cm})$, indicating they may have come from the same individual. A right astragal is complete (Fig. 4.11). Finally, from the pedal skeleton, the right Metatarsus IV (Fig. 4.14) was found in the sediment dump in front of the cave during a sieving program in 2005. A fractured femur and metacarpus appeared freshly broken.

\section{Discussion}

Processing of samples from the Srbsko-Komin hyena den showed that about $60 \%$ of the sediment was hyena coprolite material. Some of the excrements were pellet aggregates, while others were single large pellets of up to $8 \mathrm{~cm}$. These single large pellets were drop-shaped, round or oval and flat on the attachment sides, the shape of the entire pellet depends on the moisture and amount of phosphate obtained by swallowing bone fragments. Bone fragments generally adhere to bone compacta and spongi- 


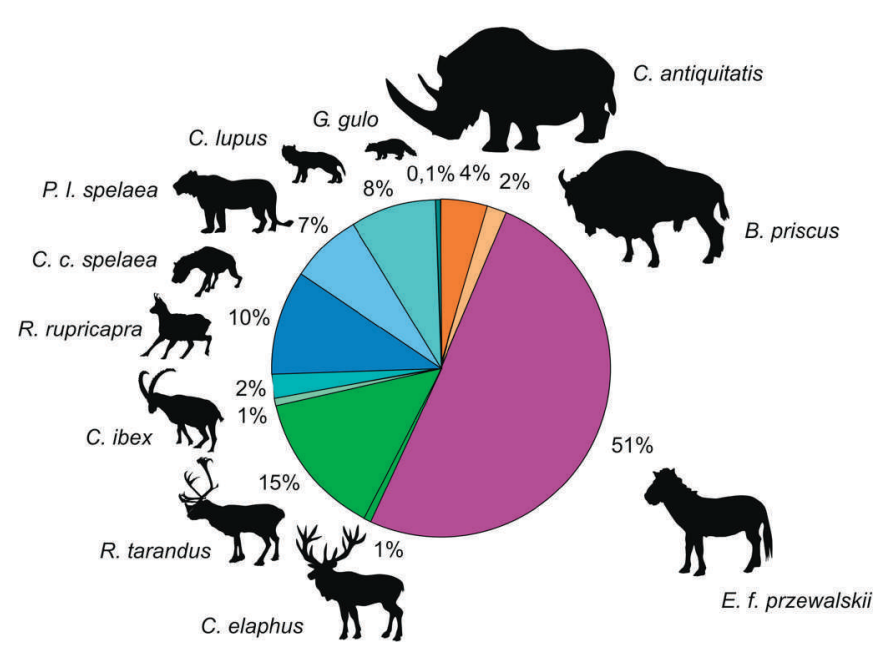

Figure 2. Percentages of hyena Crocuta crocuta spelaea (Goldfuss) prey remains in the Srbsko Chlum-Komín vertical cave ( $n=3,569$ bones) (after Diedrich and Žák, 2006).

osa fragments, which are then rounded by stomach acids (Diedrich, 2006; Diedrich and Žák, 2006). Such pellets were often trampled, building a phosphatic yellow-to-white layer in the cave sediments. The fecal pellet markings (Bearder and Randall, 1978; Fosse et al., 1998; Diedrich and Žák, 2006) and the megafauna assemblage, with its preservation, along with the large quantity of hyena remains, confirm the site as a well-frequented and longterm hyena-den cave site (Diedrich and Žák, 2006).

We compared the wolverine bone material to modern wolverines of Canada (Collection of Archeozoology, University Alberta, Canada), a well-preserved skeleton from the Salzofenhöhle in the Tote Gebirge (Pacher and Döppes, 1997), Pleistocene material from the catalogue of the Middle European sites (Döppes, 2001), and material from the German Perick Caves (Diedrich and Döppes, 2004). The small complete mandibles (lengths 10.7 to $10.9 \mathrm{~cm}$ ) indicate females (Döppes, 2001), as do the tibiae and the radius. The ulna was consistent with the length of larger males. The other material is not useful for sex identification. All material appears to be from adult animals; juveniles are absent. Predation or scavenging on wolverines is evident primarily in the mandible remains, which were cracked out of the skulls by hyenas or other carnivores (e.g., Diedrich, 2006). A few wolverine skull fragments were also discovered, although postcranial bones are generally intact and show no evidence of chewing.

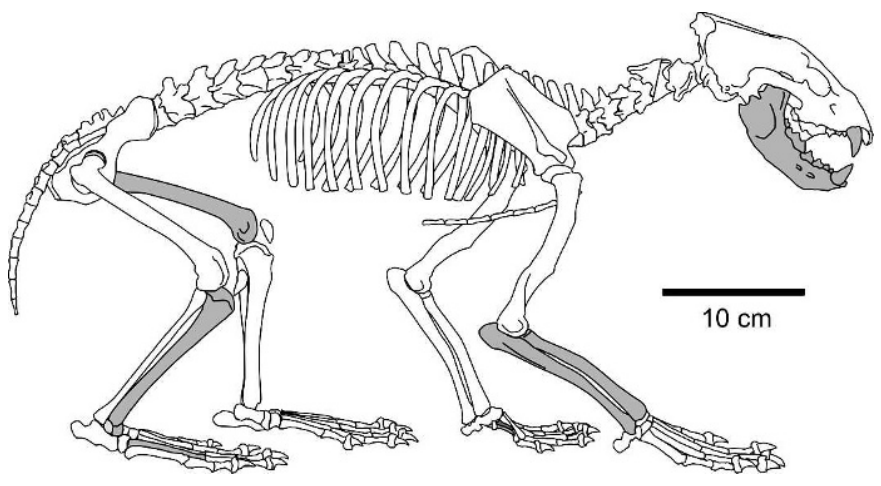

Figure 3. Anatomical locations of bones of three adult-tosenile Gulo gulo (Linné, 1758) individuals from the Upper Pleistocene Srbsko Chlum-Komin Cave, Bohemian Karst, Czech Republic. See Figure 4 and Table 1 for details on the bones.

The presence of wolverine in the Komin is most likely due to predation or scavenging. Wolverines, as scavenging carnivores themselves, may have been drawn to carrion in the cave, such as reindeers (Fig. 5), which also have been found in the Srbsko Komin Cave, leaving them vulnerable to larger predators such as hyenas, or they may have been preyed upon and transported to the cave. While the ecology of Pleistocene wolverines is unclear, contemporary wolverines are not known to use caves for anything other than periodic resting or foraging sites (Magoun and Copeland, 1998). Wolverines produce their young during winter, and reproductive den sites are most commonly reported as occurring within the snow layer or associated with woody debris or boulder structures beneath the snow layer (Magoun and Copeland, 1998). Overhanging cliffs and shallow caves are occasionally used as secondary dens and rendezvous sites (Magoun and Copeland, 1998), but use of caves that are protected enough to preserve the remains of either wolverines or their prey has not been reported for modern wolverines. Additionally, reproductive den sites of contemporary wolverines are often characterized by the presence of latrine sites wherein large numbers of scats are present. Had caves been used as reproductive dens by Pleistocene wolverines, one might expect the presence of such latrines. The lack of wolverine corprolites in the Komin also precludes the possibility that wolverines fell into vertical passageways, as has been reported by White et al. (1984) and Parmalee (1967), which can not be concluded for the Srbsko-Cave at all. Predation

Figure 4. Gulo gulo (Linné, 1758) remains from the Upper Pleistocene Srbsko Chlum-Komin Cave, Bohemian Karst, Czech Republic. NMP = National Museum Prague. 1. Right mandible of an adult animal (NMP No. R 4376), lateral. 2. Right mandible of an adult animal (NMP No. R 4377), lateral. 3. Left mandible of an adult animal (NMP No. R 4858 ), lateral. 4. Right mandible of a senile animal (NMP No. R 4853), lateral. 5. Canine of a senile animal (NMP No. R 4202), lateral. 6. Right radius of an adult-senile animal (NMP No. R 4257), cranial. 7. Right ulna of an adult-senile animal (NMP No. R 4256), lateral. 8. Left femur of an adult-senile animal (NMP No. Ra 3764), cranial. 9. Right tibia of an adult-senile animal (NMP 


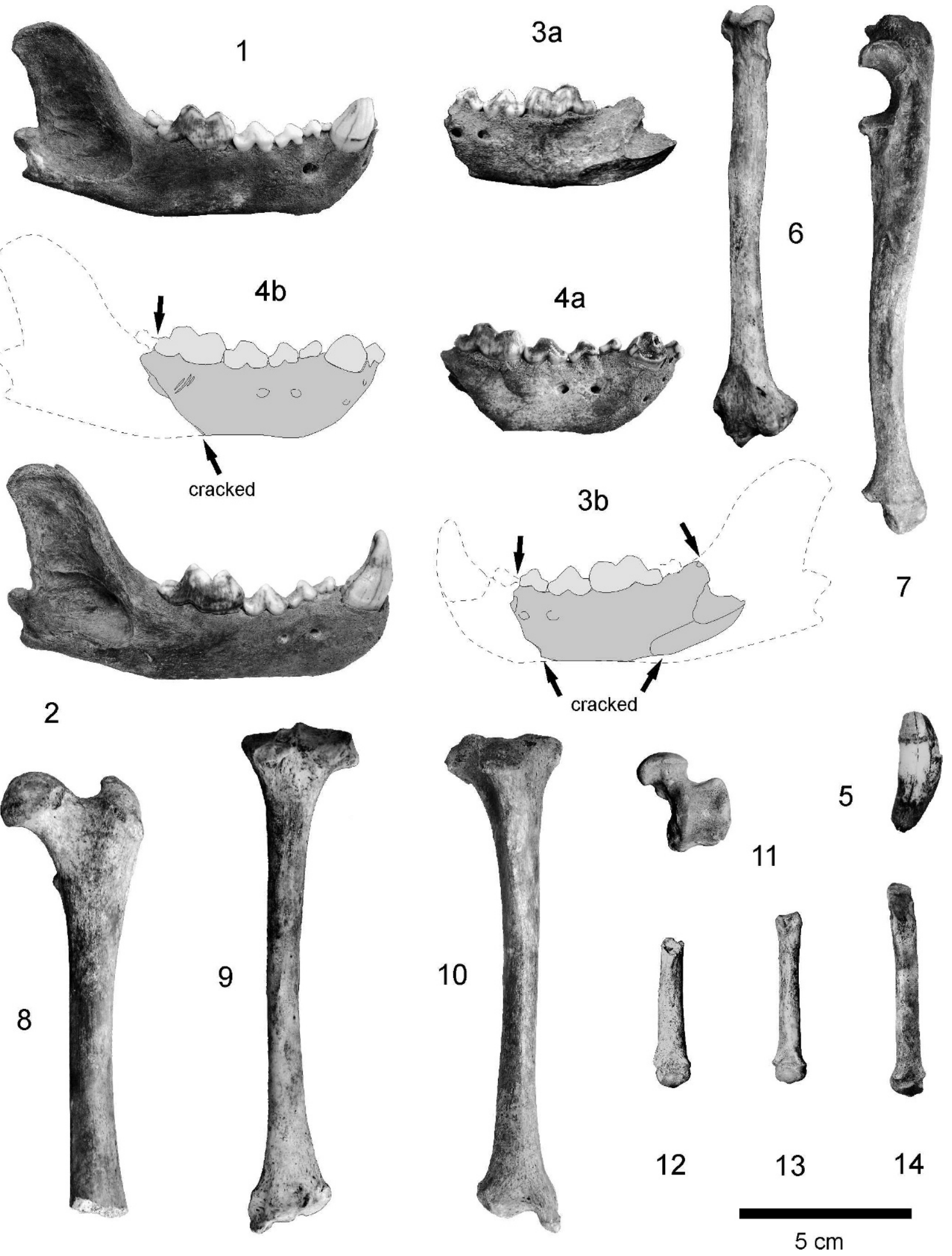

No. Ra 3765), caudal. 10. Right tibia of an adult-senile animal (NMP No. R 5320), cranial. 11. Right astragal of an adultsenile animal (NMP No. R 4378), dorsal. 12. Metacarpal bone fragment (NMP No. $R$ 4204), cranial. 13. Left metacarpal IV of an adult-senile animal (NMP No. R 4203), cranial. 14. Right metatarsal IV (Museum of the Bohemian Karst Beroun without number), cranial. 
Table 1. Gulo gulo (Linné, 1758) bone remains from the Upper Pleistocene Srbsko-Chlum-Komin Cave, Bohemian Karst, Czech Republic.

\begin{tabular}{|c|c|c|c|c|c|c|c|c|c|}
\hline No. & $\begin{array}{l}\text { Coll.- } \\
\text { No. }\end{array}$ & $\begin{array}{l}\text { Locality and } \\
\text { Collector }\end{array}$ & $\begin{array}{l}\text { Bone } \\
\text { Type }\end{array}$ & Remarks & Left & Right & $\begin{array}{l}\text { Individual } \\
\text { Age }\end{array}$ & $\begin{array}{c}\text { Photoplate } \\
\text { Original }\end{array}$ & Collection \\
\hline 1 & R 4376 & $\begin{array}{r}\text { Chlum-Komin } \\
\text { (Beneš 1968) }\end{array}$ & $\begin{array}{c}\text { Mandible } \\
\text { (length } \\
8.7 \mathrm{~cm} \text { ) }\end{array}$ & $\begin{array}{l}\text { Nearly } \\
\text { complete, } \\
\text { without } I_{1-3}\end{array}$ & & $\mathrm{x}$ & Senile & $\mathrm{x}$ & $\begin{array}{l}\text { National Museum } \\
\text { Prague }\end{array}$ \\
\hline 2 & R 4377 & $\begin{array}{r}\text { Chlum-Komin } \\
\text { (Beneš 1968) }\end{array}$ & $\begin{array}{c}\text { Mandible } \\
\text { (length } \\
8.9 \mathrm{~cm})\end{array}$ & $\begin{array}{l}\text { Nearly } \\
\text { complete, } \\
\text { without } \mathrm{I}_{1-3} \text {, } \\
\mathrm{M}_{2}\end{array}$ & & $\mathrm{x}$ & High Adult & $\mathrm{x}$ & $\begin{array}{l}\text { National Museum } \\
\text { Prague }\end{array}$ \\
\hline 3 & R 4858 & $\begin{array}{r}\text { Chlum-Komin } \\
\text { (Beneš 1971) }\end{array}$ & Mandible & With $\mathrm{P}_{3-4}, \mathrm{M}_{1}$ & $\mathrm{x}$ & & Senile & $\mathrm{x}$ & $\begin{array}{l}\text { National Museum } \\
\text { Prague }\end{array}$ \\
\hline 4 & R 4853 & $\begin{array}{r}\text { Chlum-Komin } \\
\text { (Beneš 1971) }\end{array}$ & Mandible & $\begin{array}{l}\text { Without ramus, } \\
\text { and } \mathrm{I}_{1}, \mathrm{M}_{2}\end{array}$ & & $\mathrm{x}$ & Senile & $\mathrm{x}$ & $\begin{array}{l}\text { National Museum } \\
\text { Prague }\end{array}$ \\
\hline 5 & R 4202 & $\begin{array}{r}\text { Chlum-Komin } \\
\text { (Beneš 1964) }\end{array}$ & Canine & Incomplete & & & Senile & $\mathrm{x}$ & $\begin{array}{l}\text { National Museum } \\
\text { Prague }\end{array}$ \\
\hline 6 & R 5317 & $\begin{array}{r}\text { Chlum-Komin } \\
\text { (Beneš 1968) }\end{array}$ & $\mathrm{I}_{2}$ & Incomplete & $\mathrm{x}$ & & Adult/Senile & & $\begin{array}{l}\text { National Museum } \\
\text { Prague }\end{array}$ \\
\hline 7 & R 4855 & $\begin{array}{r}\text { Chlum-Komin } \\
\text { (Beneš 1971) }\end{array}$ & $\mathrm{I}_{3}$ & Incomplete & & $\mathrm{x}$ & Adult/Senile & & $\begin{array}{l}\text { National Museum } \\
\text { Prague }\end{array}$ \\
\hline 8 & R 4257 & $\begin{array}{r}\text { Chlum-Komin } \\
\text { (Beneš 1965) }\end{array}$ & $\begin{array}{l}\text { Radius } \\
\quad \text { (length } \\
10.3 \mathrm{~cm} \text { ) }\end{array}$ & Complete & & $\mathrm{x}$ & Adult/Senile & $\mathrm{x}$ & $\begin{array}{l}\text { National Museum } \\
\text { Prague }\end{array}$ \\
\hline 9 & R 4256 & $\begin{array}{r}\text { Chlum-Komin } \\
\text { (Beneš 1964) }\end{array}$ & $\begin{array}{l}\text { Ulna } \\
\text { (length } \\
12.2 \mathrm{~cm} \text { ) }\end{array}$ & Complete & & $\mathrm{x}$ & Adult/Senile & $\mathrm{x}$ & $\begin{array}{l}\text { National Museum } \\
\text { Prague }\end{array}$ \\
\hline 10 & R 4204 & $\begin{array}{r}\text { Chlum-Komin } \\
\text { (Beneš 1964) }\end{array}$ & Metacarpus & Fragment & & & $?$ & $\mathrm{x}$ & $\begin{array}{l}\text { National Museum } \\
\text { Prague }\end{array}$ \\
\hline 11 & R 4203 & $\begin{array}{r}\text { Chlum-Komin } \\
\text { (Beneš 1964) }\end{array}$ & Metacarpus & IV & $\mathrm{x}$ & & Adult/Senile & $\mathrm{x}$ & $\begin{array}{l}\text { National Museum } \\
\text { Prague }\end{array}$ \\
\hline 12 & Ra 3764 & $\begin{array}{r}\text { Chlum-Komin } \\
\text { (Fejfar 1964) }\end{array}$ & Femur & $\begin{array}{l}\text { Without } \\
\text { distal joint }\end{array}$ & $\mathrm{x}$ & & Adult/Senile & $\mathrm{x}$ & $\begin{array}{l}\text { National Museum } \\
\text { Prague }\end{array}$ \\
\hline 13 & Ra 3765 & $\begin{array}{l}\text { Chlum-Komin } \\
\text { (Fejfar 1964) }\end{array}$ & $\begin{array}{l}\text { Tibia } \\
\text { (length } \\
11.6 \mathrm{~cm} \text { ) }\end{array}$ & Complete & & $\mathrm{x}$ & Adult/Senile & $\mathrm{x}$ & $\begin{array}{l}\text { National Museum } \\
\text { Prague }\end{array}$ \\
\hline 14 & R 5320 & $\begin{array}{r}\text { Chlum-Komin } \\
\text { (Beneš 1972) }\end{array}$ & $\begin{array}{l}\text { Tibia } \\
\text { (length } \\
11.6 \mathrm{~cm} \text { ) }\end{array}$ & Complete & & $\mathrm{x}$ & Adult/Senile & $\mathrm{x}$ & $\begin{array}{l}\text { National Museum } \\
\text { Prague }\end{array}$ \\
\hline 15 & R 4378 & $\begin{array}{r}\text { Chlum-Komin } \\
\text { (Beneš 1968) }\end{array}$ & Astragalus & Complete & & $\mathrm{x}$ & Adult/Senile & $\mathrm{x}$ & $\begin{array}{l}\text { National Museum } \\
\text { Prague }\end{array}$ \\
\hline 16 & $\begin{array}{l}\text { Srbsko- } \\
\text { G1 }\end{array}$ & $\begin{array}{l}\text { Chlum-Komin } \\
\text { (Diedrich } \\
\text { 2005) }\end{array}$ & Metatarsus & IV & & $\mathrm{x}$ & Adult/Senile & $\mathrm{x}$ & $\begin{array}{l}\text { Museum } \\
\text { Bohemian Karst } \\
\text { Beroun }\end{array}$ \\
\hline
\end{tabular}

upon wolverines by conspecifics (Persson, 2003; Krebs et al., 2004), mountain lions (Puma concolor) (Krebs et al., 2004), and wolves (Burkholder, 1962) indicates the vulnerability of the species to large predators, which likely included the European hyena during the Late Pleistocene. The practice of modern African spotted hyenas (Crocuta crocuta crocuta) to kill and scavenge other predators up to lion sizes is evidenced by numerous descriptions of the bones of prey species at modern hyena dens (Sutcliffe,
1970; Kruuk, 1972; Scott and Klein, 1981) and recently proven for Late Pleistocene (Crocuta crocuta spelaea) hyena dens (Diedrich, 2009a). The lack of wolverine corprolites and the association of chewed wolverine bones with numerous other macromammal remains in other preystorage cave sites (Diedrich and Žák, 2006) support our contention that wolverines were most likely killed at or near the cave and transported there to be eaten by hyenas, such as recently proposed for two other Late Pleistocene 


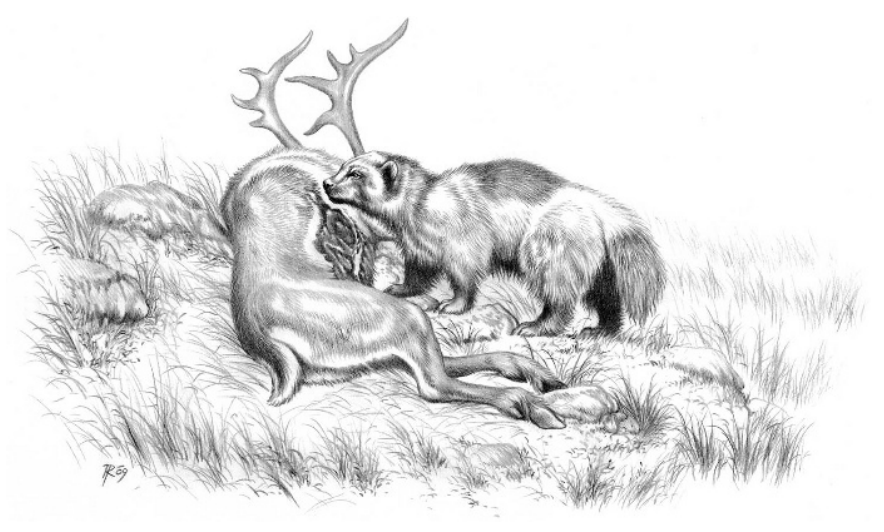

Figure 5. Wolverine on reindeer carcass near the Srbsko Chlum-Komin Cave, Bohemian Karst, Czech Republic (illustration courtesy of G. "Rinaldino" Teichmann by permission).

hyena den sites, the Sloup Cave (Czech Republic: Diedrich, 2009b), and the Perick Caves (Germany: Diedrich, 2008).

\section{ACKNOWLEDGEMENTS}

Access to the collection and loans of bone material from the Museum of the Bohemian Karst Beroun was possible by the support of I. Jančaŕíková. The head of the Department of Palaeontology, K. Zagoršek, supported our study of their Pleistocene collection. The Speleological Club Praha, especially K. Ryšánek, facilitated trips to the Srbsko-Chlum Cave. K. Žák shared his knowledge of Bohemian Caves. M. Schwartz and J. Squires provided useful comments on early versions of the manuscript.

\section{REFERENCES}

Bearder, S.K., and Randall, R.M., 1978, The use of fecal marking sites by spotted hyaenas and civets: Carnivore, v. 1, p. 32-48.

Beneš, J., 1970, Pleistocénní savci z Chlumu u Srbska (Čechy): Časopis Národního Muzea, Oddíl př́rodovědný, v. 137, no. 3/4, p. 17-26.

Burkholder, B.L., 1962, Observations concerning wolverine: Journal of Mammalogy, v. 43, p. 263-264.

Diedrich, C., 2006, The Crocuta crocuta spelaea (Goldfuss 1823) population from the early Upper Pleistocene hyena open air prey deposit site Biedensteg near Bad Wildungen (Hess, NW Germany) and contribution to their phylogenetic position, coprolites and prey: Cranium, v. 23, no. 1, p. 1-15.
Diedrich, C., 2007, Bone crackers and carcass accumulators in Central Bohemia-Late Pleistocene hyenas and their cave den and prey depot types: Scripta Facultatis Scientiarum Universitatis Masarykianae Geology, v. 35, p. 91-96.

Diedrich, C., 2008, Die letzen Vielfraße Gulo gulo (Linné, 1758) aus den Perick- und Rösenbecker Höhlen im Sauerländer Karst: Mitteilungen des Verbandes der deutschen Höhlen- und Karstforscher, v. 54, no. 2, p. 36-44.

Diedrich, C., 2009a, Steppe lion remains imported by Ice Age spotted hyenas into the Late Pleistocene Perick Caves hyena den in Northern Germany: Quaternary Research, v. 71, no. 3, p. 361-374.

Diedrich, C., 2009b, A Late Pleistocene wolverine Gulo gulo (Linné, 1758) skeleton remain from the Sloup Cave in the Moravian Karst, Czech Republic: Annalen des Naturhistorischen Museums Wien, v. 110A, p. $123-132$.

Diedrich, C., and Döppes, D., 2004, Oberpleistozäne Vielfraßreste (Gulo gulo Linné 1758) aus dem Perick-Höhlensystem im Sauerland (NW Deutschland): Philippia, v. 11, no. 4, p. 335-342.

Diedrich, C., and Žák, K., 2006, Prey deposits and den sites of the Upper Pleistocene hyena Crocuta crocuta spelaea (Goldfuss 1823) in horizontal and vertical caves of the Bohemian Karst (Czech Republic): Bulletin of Geosciences, v. 81, no. 4, p. 237-276.

Döppes, D., 2001, Gulo gulo (Mustelidae, Mammalia) im Jungpleistozän Mitteleuropas: Beiträge zur Paläontologie, v. 26, p. 1-95.

Fosse, P., Brugal, J.P., Guadelli, J.L., Michel, P., and Tournepiche, J.F., 1998, Les repaires d' hyenes des cavernes en Europe occidentale: presentation et comparisons de quelques assemblages osseux, in Economie Prehistorique: Les comportements de substance au Paleolithique, XVIII Rencontres internationales d' Archeologie et d' Historie d' Antibes, Sophia Antipolis, Editions APDCA, p. 44-61.

Krebs, J., Lofroth, E., Copeland, J., Banci, V., Golden, H., Magoun, A., Mulders, R., and Shults, B., 2004, Synthesis of survival rates and causes of mortality in North American wolverine: Journal of Wildlife Management, v. 68, p. 493-502.

Kruuk, H., 1972, The Spotted Hyena: A story of predation and social behavior, Chiciago, University of Chicago Press, $352 \mathrm{p}$.

Magoun, A.J., and Copeland, J.P., 1998, Characteristics of wolverine reproductive den sites: Journal of Wildlife Management, v. 62, no. 4, p. $1313-1320$.

Pacher, M., and Döppes, D., 1997, Zwei Faunenelemente aus pleistozänen Höhlenfundstellen des Toten Gebirges: Canis lupus L. und Gulo gulo L.: Geologische und Paläontologische Mitteilungen Innsbruck, v. 22, p. $129-151$

Parmalee, P.W., 1967, A recent cave bone deposit in south-western Illinois: Bulletin of the National Speleological Society, v. 29, p. 119-147.

Persson, J., 2003, The role of intraspecific predation in the survival of juvenile wolverines Gulo gulo: Wildlife Biology, v. 9, p. 21-28.

Scott, L., and Klein, R.G., 1981, A hyena accumulated bone assemblage from late holocene deposits at Deelpan, Orange Free State, South Africa: Annals of the South African Museum, v. 86, p. 217-227.

Sutcliffe, A.J., 1970, Spotted Hyena: Crusher, gnawer, digester and collector of bones: Nature, v. 227, p. 110-113.

White, J.A., McDonald, H.G., Anderson, E., and Soiset, J.M., 1984, Lava blisters as carnivore traps, in Genoways, H.H., and Dawson, M.R., eds., Contributions in Quaternary Vertebrate Paleontology: A Volume in Memorial to John E. Guilday, Pittsburgh, Carnegie Museum of Natural History Special Publication 8, p. 241-256. 